\title{
Research of the Teachers' Psychological Status of Chongqing Private Colleges
}

\author{
LI Jiliang ${ }^{1, a}$ \\ ${ }^{1}$ Chongqing Normal University Foreign Trade and Business College, Chongqing 401520 ,China \\ a Lijiliang2013@yeah.net
}

\begin{abstract}
keywords: Private colleges; The teacher; Pressure; Mental health; Influencing factors; Countermeasures
\end{abstract}

\begin{abstract}
Teachers of private college, their mental health not only directly affect the school-running level and teaching quality, but also affect the mental health of students. Private schools teachers, the special occupational group suffers from the phenomenon of psychological stress. Factors that lead to teachers' psychological stress include social pressure, school work environment level. To alleviate the pressure of the private school teachers, social support system must be set up; School administrators should establish the scientific management awareness to support private schools teachers' work, create good working environment for private school teachers; Private school teachers should learn to carry out self-psychological adjustment and self-support as well.
\end{abstract}

\section{Introduction}

Private college teachers are an important component of college teachers, and carry on the investigation of the mental health status is very necessary. Psychological pressure reflects the fact that individual is exposed to stress in life practice and form a kind of comprehensive psychological shape. According to statistics, in the current college entrance examination baton command and employment pressure cases, $50 \%$ of the teachers suffer from psychological stress syndrome. With the vigorous development of private education, private college teachers are receiving more and more social attention. As interpersonal relationship and the education object, etc., in constant collision the teachers are bound to be faced with more heavy psychological pressure. Studies have shown that undue pressure continuously, is one of the main causes of disease of body and mind.[1] Heavy psychological pressure, therefore, will harm the physical and mental health of private school teachers, which affects the healthy growth of students in private schools.

\section{The Analysis of the Causes of Private College Teachers' Psychological Problems}

a. As to private university teachers' career, private colleges' teachers are engaged in a very complex mental work, the level of intelligence in the process of their labor being high. Most private colleges' teachers need at the same time in the education teaching, education, scientific research and social services in areas such as the fruitful work. Colleges and universities is to cultivate senior specialized talents, the teaching content has some exploratory. Visible, run by the local university teachers' career is a creative, complexity and long term in the stress state of a kind of intelligent type, spirit, professional, and easy to form a professional job burnout. The particularity of teachers' professional determines the private college teachers' psychological often in a state of overload[2].

b. From the point of view of private colleges and universities teacher's, private colleges teachers play the role of a worthy example. Social expectations put on private college teachers are also increasingly high. The occupational stress is reflected in the conflict between traditional ideas and social reality. Conventional wisdom suggests that teachers should be selfless, dedicate, to value justice above benefit, but with the widening income gap in the social from all walks of life, the problem that teachers' salary and low social status becomes increasingly obvious. More effort while 
less harvest reflects the strong contrast that adds the teachers' psychological pressure.

c. As for psychology. American psychologist Maslow's humanism, in regard to people's mental health problems, said the person's psychology health level is associated with the satisfaction of needs and the more the needs are satisfied, the higher the person's mental health. According to the theory, meeting the requirement of security and realizing sense of belonging are the basis of the achievement of self-esteem, self-fulfillment. Teachers of private colleges and universities generally, however, lack the sense of security, belonging and achievement, which gives private colleges' teachers huge psychological pressure, and limits their further development.

d. When it comes to system, system is a code of conduct of human social practice; it regulates the social organization of the relationship of the people. System is a social consensus, and each member must abide by. Once established, the system will remain the same in a long time.[3] Private colleges, having a history of over decade of development, all kinds of system have accordingly established. However, various non-governmental university systems have a common problem that there is too much and fast change. System changes frequently, resulting in the non-governmental university teachers' inadaptability and they have to struggle to keep up, adding to the private colleges and universities teachers' psychological burden.

e. From the economics perspective. A school is a team, the team's development cannot leave the team spirit, and team spirit is not to avoid interest motivation. Interest distribution must adhere to the principle of fairness and justice, to be closely linked to benefits, contribution, profit margins, but also to the difficulty of the different positions. Private colleges put excessive emphasis on collectivism selfless dedication while ignore the interest of teachers, private college teachers facing economic pressure, also became the important cause of private college teachers' psychological pressure.

\section{The Basic Strategy to Alleviate the Psychological Pressure of the Private School Teacher}

\section{a. Establish a social support system}

(1) The government should formulate and perfect relevant special regulations, make specific provisions to the holders and the operators of private schools, for the holders and the operators of private schools must ensure that teachers have other benefits except the wage, so as to alleviate the pressure of private teachers survive and life risk.

(2) Coordinate the relationship between the teachers and parents. The education of modern society is an open system. Family and social factors, with strong radiation, is affecting the school education. We can not ignore psychological stress of the teachers caused by the family. But if private schools intended to improve the education quality of teaching to ease the pressure from parents silently and alone, it is unwise and almost impossible.[4] Therefore, schools should strengthen the contact between family and teachers to obtain parents' understanding and support so that relieve high psychological pressure from society, family expectations.

(3) For the government to intensify propaganda, calling on the whole society to concern, support and cooperate with teachers in private schools, make teachers in an atmosphere of being loved, understood, and respected, alleviate the psychological pressure of the inferior.

\section{b. Improve the working environment of private school teachers}

(1) School administrators should establish the scientific management idea; establish the idea of teachers is the most valuable resources. Fundamentally to realize the difference between enterprise and school, the teachers can't be treated as production machine, on the premise of emphasizing on education teaching ability, establish a set of incentive oriented teachers management system and 
mechanism, arouse the enthusiasm of teachers' individual and group, set up humanistic concept, grateful for the staff.

(2) Evaluate of teachers' creative work correctly; establish the mechanism of the evaluation of teachers' developmental; provide a fair and reasonable, open and orderly competition environment for teachers. [5]Work teachers engaged in is creative work. As a non-government school administrator, when evaluate a teacher's work, first to tap into its value creation, must pay the labor, the achievement and experience give praise, promotion, make teachers feel that their work is valuable, which will make work effective.

(3) Provide teachers with more free time, and make efforts to create loose work environment for teachers. School administrators should be to a certain extent, solve the problem of teachers' labor overtime. For example, improve teaching efficiency and flexible office system; Under the condition of may reduce class places, let the teachers take the initiative to participate in work and leisure, make teachers' mental and physical strength has a primary activity; Public schools can try to break the traditional paternalism.

\section{c. The private school teachers should learn to carry out self-psychological adjustment and self-support.}

(1) Control the pressure effectively.First, form pressure immunity, and establish the awareness to treat pressure correctly. Second, take a positive stress coping styles. In particular, to take the initiative to adapt to the environment, consciously adjust them, to transfer mode to active mode, to deal with the problem of sentiment orientation to cope with steering. [6]Again, take the initiative to seek social support. In psychology, social support is a particular relationship, but a person to meet the psychological pressure, he can get from the relationship social support and effective help. Such as husband and wife, parents, friends and so on, all is the strength of social support. Research shows that social support level will directly affect the individual's psychological health level, the higher the level of social support, the higher mental health level is, the higher the degree of subjective well-being, the less psychological symptoms.

(2) Learn to regulate emotions, relieve stress. The teacher in the nervous learning outside of work, to carry out a variety of business activities, such not only can regulate teachers nervous rhythm of life, make the mood relax, alleviate psychological pressure. Can edify disposition again at the same time, make the person mind cheerful, strengthen the psychological bearing capacity. For private school teachers, in the spring tide of market economy involved in the private education experience with/happiness of person of outstanding ability and teach all over the world, at the same time, under psychological stress in many ways. We should pay attention to the private school teachers' psychological pressure, thinking about it, analyze it, and then try to reduce it, the purpose is to make private schools have a small team of teachers, so as to improve the quality of China's non-governmental education cause, training more qualified personnel.

\section{Summary}

For private school teachers, in the tide of being involved in the private education they have the pleasure of getting talents from all of the word, but at the same time, they are also under psychological stress in many ways. We should pay attention to the private school teachers' psychological pressure, think about it, analyze it, and then try to reduce it, the purpose being to make private schools have an expert team of teachers, so as to improve the quality of China's non-governmental education cause and have qualified personnel.

\section{Reference}

[1] Renbo, Yangyan,ZhouFentong, Tianjin university teachers psychological health situation 
analysis and countermeasures[J], Journal of tianjin university, 200911(3): 285- 288.

[2] Wuanchun,Chenmin, Chongqing four colleges and universities teachers' mental health status surveys and analysis[J], Journal of Chongqing Jiaotong University;2010,10(5): 100- 103.

[3] Maquanyan,Bailimin,Sunmingxin, The investigation of present situation of ordinary colleges and universities teachers' mental health[J], Journal of liaoning university of science and technology

[4] Liukeshan, The meaning and characteristics of psychological stress[J], Journal of Hengyang normal university, , 2003. 2. 102-106

[5] Liuqizhen, Primary and secondary school teachers psychological stress relieve[J], Education comments, 1998.2.22-24

[6] Huwei, The development of private education and specifications[M],Beijing: education science press, 2000.246 